\title{
非切除, 非手術末期胃癌に対する癌化学療法の臨床的研究
}

一MMC 㧊よび MFG 療法を中心として一

\author{
東京医科大学外科学教室（指導：牧野惟義教授） \\ 助手: 竹 口 甲 二
}

CLINICAL STUDY OF CANCER CHEMOTHERAPY FOR UNRESECTABLE

AND INOPERABLE GASTRIC CANCER -ESPECIALLY ON MMC AND MFC THERAPY-

Khoji TAKEGUCHI

Department of Surgery, Tokyo Medical College

(Director : Professor Koreyoshi Makino)

胃癌の治療に当っては，現在迄のところ手術療法が最も有効であるといらことは異論の ないところであるが，この手術寮法から見はなされた切除不能および手術不可能な所謂末 期胃癌の治療成績向上のために癌化学療法を行ない, 臨床的効果, 延命効果, 副作用, 病 理組織学的効果などについて検討を行った。

62例の非切除および非手術末期胃癌に対して癌化学療法 (I 群 MMC単独療法36例, II 群 MFC 療法26例) を行ない21例のコントロール群と比較検討した。

日本癌治療学会効果判定基準による軽快率は MMC群 $27.8 \%$, MFC群 $34.6 \%$ ，Karnofsky 基準の 1-A 以上は $\mathrm{MMC}$ 群 $22.2 \% \mathrm{MFC}$ 群 $34.6 \%$ と対照群に比べ明らかな奻果を 示した。また，MFC群では Karnofsky の1-Cを2例認めた。

延命効果は，対照群に比し， MMC群では 50\%生存日数で56日，平均生存日数で69.3 日，MFC群では $50 \%$ 生存日数で 63 日，平均生存日数で98.2日の延長を見た.

副作用は血液学的副作用として白血球減少, 自覚的副作用として食欲不振が主なもので あり，両群共に認められるが MFC群では，MMC群に比べ出現率が高く認められた。

経封的に内視鏡による胃生検を行ない病理組䄉学的効果について検討を行なったが，効 果は大星らの Grade II в 迄であった。 また, 臨床的效果と病理組織学的効果はほぼ相関 関係を示した。

MMC 療法, MFC療法ともに末期胃癌の寛解導入療法として有効であった。

治療効果の点では MFC療法が優れ, 副作用の点では MMC 療法の方が軽度であった. 従って症例に応した使い分けが必要である。

\section{第 1 章 緒 言}

近年, 胃癌診断治療技術の進歩は目ざましく，早期発 見，早期治療が高率に行なわれる様になり，多くの施設 で早期胃癌の術後 5 年生存率 $90 \%$ 以上を報告する現況で ある、しかるにこれを胃癌全体について眺めてみると末
たに進行癌が王倒的多数を占め，非治瘁切除例を除いた 治缷切除例の 5 年生存率 でも，約 $40 \%$ 内外と 低率であ る. 従つて切除不能な，あるいは手術不可能な所謂末期 胃癌では治療成績は低く，3 年以上生存例はごく稀であ るのが現状である゙。 
胃癌の治療に当つては，現在迄のところ手術療法が最 も有効であるといらことには異論のないところである か，手術手技と外科的治滰には自ら限界がある，徒つて 治療成績を向上させるためには手術療法に加克て補助療 法として, 放射線療法, 化学療法, 免疫療法などが遍く 行なわれている。

即ち，胃癌の治療成績の向上のためには，早期癌につ いては，各施設報告者間にそれはどの盖はなく，ほぼ満 足すぺき結果が得られているが進行癌については今後な お充分検討の余地が残されている.殊に，非切除，非手 術末期胃癌についての残された治療法としては現在まて のところ, 化学療法, 放射線療法, 免疫療法などについ て，単独または併用の療法を施行する事が主たる治療法 になろかけである。この点に鑑み著者らは化学療法にお いて1968年以来諸種の検討を加えて来たが特に非切除， 非手術末期胃癌の治療成䋶向上のための研究の一環とし て, 癌化学療法の効果を検討する目的で本研究を行つ た.

\section{第 2 章 研究対象および方法}

\section{第 1 節 対象}

教室に括ける1968年 1 月から1977年12月末迄の，10年 間の胃癌総症例数は表 1 の如く1,412例であり，そのう ち非切除末期胃癌は243例（17.2\%）であつた．非手術 例は99例 (7.0\%) であったが，このらち初回手術を他 施設で行った. Non primary case，手術拒否例などを除 き，䠦床的に末期胃癌と考元られる症例は84例（5.9\%） で, 合計，非切除，非手術末期胃癌は327例 (23.2\%) を対象とした。

末期胃癌の治療法別内訳は表 2 の如くで, 非切除例で 化学療法のみを施行したものは，98例 (40.3\%) であ り, 非手術例で化学療法のみを施行したものは，25例 (29.8\%)であった。

今回対象とした症例は，この非切除，非手術末期胃 癌のうち化学療法のみを施行した症例で Mitomycin C

表 1 胃榣应例内訳 $(1968 ， 1 １ 977 ， 12 ） （ \%)$

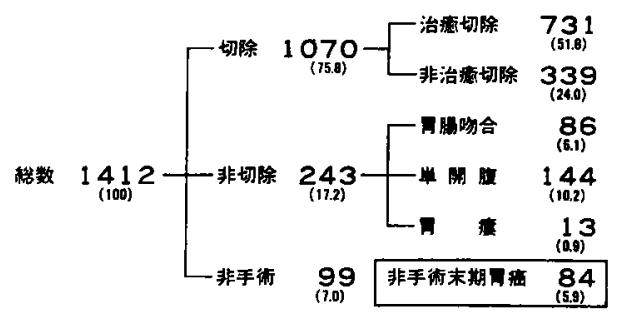

表 2 末期胃癌の治㞠法別内訳（1968． 1 1977. 12) $(\%)$

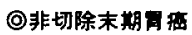

\begin{tabular}{|c|c|c|c|c|c|}
\hline 手術ん式 & 手術のみ & 手十照射 & 手十化䗝 & 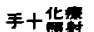 & It \\
\hline 田獥吻合 & 24 & 10 & $\begin{array}{l}37 \\
(15.2)\end{array}$ & $\begin{array}{l}15 \\
{ }_{(6.2)}\end{array}$ & $\underset{(35.4)}{88}$ \\
\hline 箠開 & 199 & 22 & $\begin{array}{l}59 \\
(243)\end{array}$ & 44 & 144 \\
\hline in & 8 & 2 & 2 & 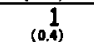 & $\frac{13}{(5.3)^{3}}$ \\
\hline 討 & $\begin{array}{l}51 \\
5(21.0)\end{array}$ & $\begin{array}{l}34 \\
(14.0)\end{array}$ & 98 & 6 & $24(100)$ \\
\hline
\end{tabular}

（）非手術末期胃活

\begin{tabular}{|c|c|c|c|c|}
\hline 照 射 & 化 & 化 + 盟 & 非治 & N \\
\hline$\sum_{\langle 28.2\rangle}$ & 25 & 199 & 18 & $\begin{array}{l}84 \\
(100)\end{array}$ \\
\hline
\end{tabular}

表 3 各群別症例内訳 (\%)

\begin{tabular}{|c|c|c|c|c|}
\hline & $\begin{array}{c}\text { I 群 } \\
\text { (MMC単独) }\end{array}$ & $\begin{array}{l}\text { II 群 } \\
\text { (MFC恶法) }\end{array}$ & $\begin{array}{l}\text { III 群 } \\
\text { (犺觜群) }\end{array}$ \\
\hline \multirow{2}{*}{ 非 } & P檑吻合 & $15(41.7)$ & $8(30.8)$ & $12(57.2)$ \\
\hline & 単開腹 & $12(33.3)$ & 11 (42.3) & 7 (33.3) \\
\hline \multirow{2}{*}{$\begin{array}{l}\text { 切 } \\
\text { 除 }\end{array}$} & 胃 点 & $0(0)$ & 1 ( 3.8$)$ & $2(9.5)$ \\
\hline & 小 計 & $27(75.0)$ & $20(76.9)$ & 21 (100) \\
\hline 非 & 手 術 & $9(25.0)$ & $6(23.1)$ & $O(0)$ \\
\hline 䌊 & 尌 & $36(100)$ & $26(100)$ & $21(100)$ \\
\hline
\end{tabular}

(以下 MMC) 単独は39例, MMC, 5-Fluorouracil (以 下 5-FU), Cytosine arabinoside (以下 CA) 併用の MFC 療法を行った31例であるが，このうち MMC 投与群で 3 例，MFC 療法群で 5 例の副作用による投与中止例を 除いた MMC 投与群36例 (以下 I 群)，MFC 療法群 26 例（以下 II 群）の計62例を研究対象とした（表 3 ）.

なお，副作用については副作用による投与中止例も加 えた【 群39例，II群31例について険索を行った。

\section{第 2 節 研究方法}

\section{第 1 項 投与薬訪並びに投与方法}

1) I 群

I 群は MMC 単独投与群で, 投与方法は, MMC $0.08 \mathrm{mg} / \mathrm{kg}$ を最初の 2 週は週 2 回, 計 4 回, 以後幅作 用の軽減の目的で週 1 回とし計 6 回, 総計 10 回, 総量 $40 \mathrm{mg} / 50 \mathrm{~kg}$ を 1 クールとし生食水 $20 \mathrm{ml}$ を加穴静脈内投 与した.

\section{2) II 群}

II 群は MFC 療法施行群である. 投与方法は MMC $0.08 \mathrm{mg} / \mathrm{kg}, 5-\mathrm{FU} 10 \mathrm{mg} / \mathrm{kg}, \mathrm{CA} 0.8 \mathrm{mg} / \mathrm{kg}$ を始めの 2 週間は週 2 回，その後は週 1 回投与し, 計 10 回, 総量 MMC $40 \mathrm{mg} / 50 \mathrm{~kg}, 5-\mathrm{FU} 5,000 \mathrm{mg} / \mathrm{kg}, \mathrm{CA} 400 \mathrm{mg} / 50 \mathrm{~kg}$ を1クールとして静脈内投与を行った。 
投与開始時期は，I 群，II 群共に，非手術例では非手 術亡決定した時点から投与を開始し，非切除例では，開 腹術後，効果判定の確実を期するため，また，副作用の 軽減のため手術の全身的影鳔が取れる，術後第10病日頃 よりクールを開始した。

\section{3) III群}

III群はコントロール群であり，1965年から 2 年間の， 我々が計画的な化学療法を開始する以前の症例で，開腹 手術を行い，且つ組織学的にも末期胃癌である事を確認 した非切除例で，且つ何ら化学療法を施行しなかった症 例の全例2I例である.

\section{第 2 項 臨床的効果判定}

1) 日本癌治療学会基準

日本癌治療学会による癌化学療法効果判定基準（以下 日癌治会基準) は表 4 亿示すように，A：腫場，B：自 覚泟状，C：他覚所見， D：検査成績により，軽快，不 変，悪化を判定するむのである．

2) Karnofsky 基隻

Karnofsky 基準は表 5 に示すように自覚的改善と他覚 的改善とを組み合わせ，更に改善期間をる考虑に入れた

表 4 淀化学寮法効果判定基準 ${ }^{24)}$

\begin{tabular}{|c|c|c|c|c|}
\hline \multicolumn{2}{|r|}{ 判 } & 定 & \multicolumn{2}{|l|}{ 項 目 } \\
\hline & (A) & $\begin{array}{c}\text { 自賞症状 } \\
\text { (B) }\end{array}$ & $\begin{array}{c}\text { 他筧所見 } \\
\text { (C) }\end{array}$ & $\begin{array}{c}\text { 検盖成維 } \\
\text { (D) }\end{array}$ \\
\hline 原発童 & 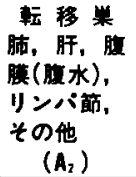 & $\begin{array}{l}\text { 1. 其欲 } \\
\text { 2. 主症状 }\end{array}$ & $\begin{array}{l}\text { 1. 体重 } \\
\text { 2. 可到性 }\end{array}$ & $\begin{array}{l}\text { 1. 血沈 } \\
\text { 2. 界血 (Hb } \\
\text { उWはR) } \\
\text { 3. A/G } \\
\text { 4. 血清鉄 } \\
\text { 5. LOH }\end{array}$ \\
\hline
\end{tabular}

\section{各項目についての判定}

A 蛙 $\cdots-26 \%--100 \%$ 不 $\cdots-25 \%-+25 \%$ 恶化 $\cdots+26 \%$ 以上

A 怢央綃少ないし消失 不裂…不恤

哥化…臺化

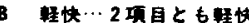
不贺…1颔目のみ快, 他 は不焉, あるいはい オれも不到

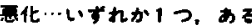
いは 2 项目とも善化

効 果 判 定

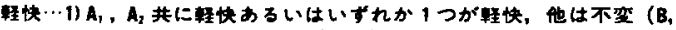
C、Dの如何にかかわらぢ㲔快） 2) $A_{1} ， A_{2}$ 㚘に不贺で，B，C、Dすへててが快

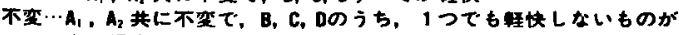
あ万婸合

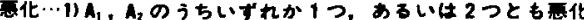
2) $A_{1}, A_{2}$ 不变 $\tau B, C$, o才へて高化

住）入院後 2 ヶ月以内に死亡した症例心効果判定から除く

\section{表 5 Karnofsky's criteria ${ }^{25)}$}

Category 0 . No clinically usefut effect on course of disease.

0.0 Disease progresses; no subjective benefit.

$0-A^{*}$ Disease progresses; subjective benefit without favorable objective changes.

O-B* Favorable objective changes without subjective benefit.

O-C Subjective benefit and favorable objective changes in measurable criteria, but of less than 1 month's duration; then the disease progresses.

Category I. Clinical benefit with favorable objective changes in all measurable criteria of disease.

I-A Distinct subjective benefit with favorable objective changes in all measurable criteria for 1 month or more.

I-B* Objective regression of all palpable or measurable neoplastic disease for 1 month or more in a relatively asymptomatic patient who is able to carry on his usual activities without undue difficulty. The observes tumor regression should be unequivocal, and it is suggested that all lesions be reduced at least $\mathbf{5 0}$ per cent in bulk. This category applies as long as the regression persists and ends if any lesion, old or new, recurs.

I-C Complere relief of symptoms, if any, and regression of all manifestations resulting from the active disease for 1 year or more. The relation to the frequency of therapy is not relevant if the disease does not recur hetween courses of therapy.

"Categories apply as long as improvement from base line persists. Superscript is time in months of duration of response, e.g., $D-A^{4}$ or $I-B^{3}$

判定法で，自覚的他覚的改善が 1 カ月以上持続する 1 A 以上を有効と考えた。

なお，効果判定は I 群，II群とも1クール10回以上の 投与を行った症例について行い副作用による投与中止 例，I 群 3 例，II 群 5 例は効果判定の項では除外した。

\section{第 3 項 延命効果}

\section{1）平均生存日数}

癌治療の究極の目標は，延命効果を得ることにある が，末期胃癌に招いては 3 年以上の 生存例を末だ認め ず， 3 年生存率， 5 年生存率などで表現することは不可 能なため，平均生存日数に上り比較検討を行った．生存 日数は化学療法開始日からの日数を笋定したが、コント ロール群である III群については，I群，II群において化 学療法が開始される術後10日目を第 1 生存日として算定 を行った。また I 群， II 群， 群の生存日数について有 意の差があるかどうかを梳計学的に検討した。

2）生存曲線と $50 \%$ 生存日数

化学療法開始後の生存状態から延命効果を検討するた めに生存曲線を作成し50\%生存日数を求めた。

横軸に化学療法開始日からの日数を，綖軸に生存例数 
の\%を取り，何\%の人が何日生さたかを出した。ここで 回群については前項と同様に術後第10病日目から算定し た.

また，生存日数の検討には，生存中の症例は除外せね ばならず，I群，II群共泟生存中の１例を除きＩ群35

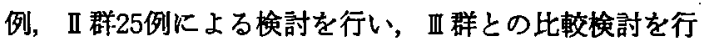
った。

\section{第 4 項 副作用}

1）検查項目扣よび発現頻度

副作用については，検查項目を，血液学的副作用とし て白血球减少 $\left(3,000 / \mathrm{mm}^{3}\right.$ 以下) 血小板減少 $\left(10\right.$ 万 $/ \mathrm{mm}^{3}$ 以下)，自覚的副作用として食欲不振，覀心呕吐，下 疮，腹痛，全身倦急，口内炎，発熱とした．また，貟 血，肝機能障害については，本研究の対象が末期胃癌で あり，原疾患によるものか，薬剤の副作用によるるのか 判定困難なため検査項目から除外した。

副作用の発現頻度は，各項目について，投与総症例数 に対する発現症例数で表わし，同一症例で副作用が重複 するむのむ，それぞれの項目に入れた．また，副作用に 上る投与中止例が I 群で 3 例，II群で 5 例あり，これら は脱落症例として, 効果判定では除外したがその原因が 副作用であるため, これらを加点 I 群総例数39例，II群 31例としここの総数に対するそれぞれの発現例数を百分 率で表わした。

2) 発現時期

副作用発現の時期を，薬珮投与開始からの期間（週数 で表わす)，および薬剤投与量から検討した。

\section{第 5 項 病理組的学的果判定}

1) 検查方法

抗癌剤の直接癌細胞に対する効果を見るために，末期 胃癌症例江経時的内視鏡に上る生検を行い組織学的効果 判定を行ったが，末期胃癌症例に反復検查を行らことは 困難で経時的生検可能症例は 8 例であった。

生検組織採取時期は, I 群 (MMC 療法), II 群 (MFC 療法) 夫ィ10回，1クールを寛解導入療法と考古，原則 として, 先ず化学療法開始前, 次に宽解導入中期として 5 回終了時，そして寞解導入終了時として10回終了時， その後維持療法中に月 1 回から 2 回の生検を行った。

2) 組織学的効果判定

組織学的効果判定は表 6 亿示寸大星 ${ }^{2}$ の判定基準によ り行った.

これは，制癌剂による死減癌細胞の融解消失後に癌胞 巣内に残される細胞欠落像，およびその結果生ずる組織

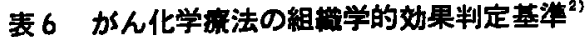

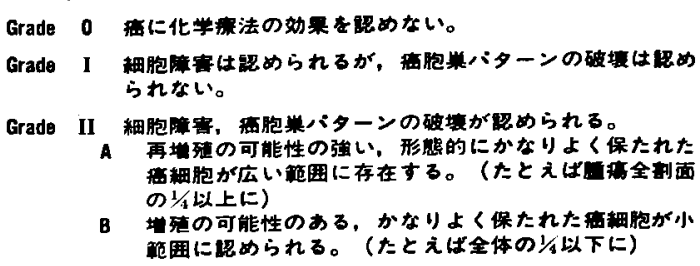

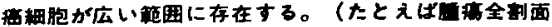
の $1 / 4$ 以上に)

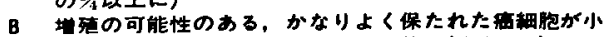
的围に思かられる。(たとえは全体の $1 / 4$ 以下に)

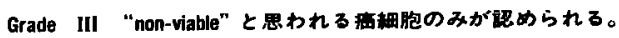

Grade IV 舫稩胞はまつたく䀓められない。

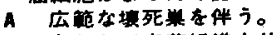

B 主として肉车組よりなる。

C㾝稿縕よりなる。

の収縮像によって示される死滅癌細胞と生存癌細胞の量 的な比に重点を圈いた判定で，細胞の变性の みを示す Grade I までは無効, 癌胞巣ハターンに変化が表われる Grade II 以上を有効とした.

\section{第 3 章 研究成綡}

第 1 節 臨床的効果判定

第 1 項 日本注治獠学的基準

日癌治会基準の結果は表 7 上段のごとくで軽快は I 群 で27.8\%，II群は34.6\%であり正群には軽快例はみられ

\section{表 7 臨床的効果判定}

日掼治会基準による効果判定

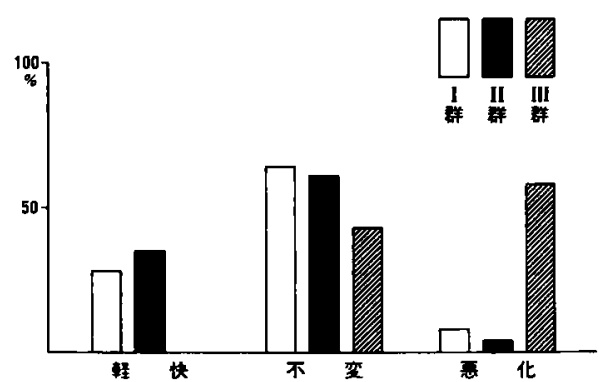

Karnofsky判定基準による効果判定

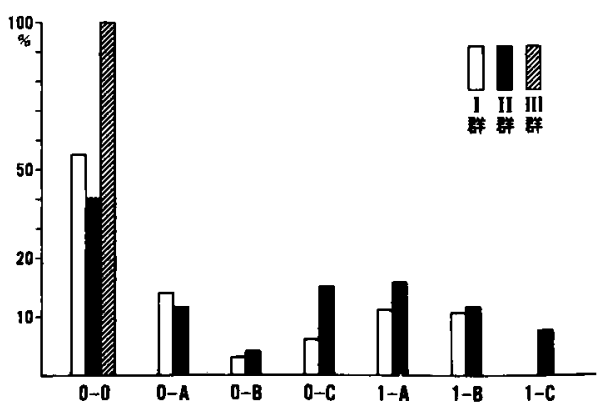




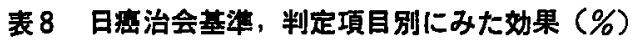

\begin{tabular}{|c|c|c|c|c|c|c|}
\hline & 軽 & 快 & 不 & 変 & 悪 & 化 \\
\hline$A_{t}$ & \multicolumn{2}{|c|}{$6^{\text {MI }}(16.7)$} & \multicolumn{2}{|c|}{27 例(75.0) } & \multicolumn{2}{|c|}{ 3制( 8.3$)$} \\
\hline I $A_{2}$ & 4 & (11.1) & 31 & (86.1) & 1 & ( 2.8) \\
\hline B & 12 & (33.3) & 14 & (38.9) & 10 & (27.8) \\
\hline 群 C & 8 & (22.2) & 21 & (58.3) & 7 & (19.5) \\
\hline D & 11 & (30.6) & 22 & (61.1) & 3 & (8.3) \\
\hline $\mathbf{A}_{1}$ & 6 & (23.1) & 19 & (73.1) & 1 & ( 3.8$)$ \\
\hline II $\mathbf{A}_{2}$ & 3 & (11.5) & 23 & (88.5) & 0 & $(0)$ \\
\hline B & 13 & (50.0) & 8 & (30.8) & 5 & (19.2) \\
\hline 群 C & 8 & (30.8) & 15 & (57.7) & 3 & (11.5) \\
\hline D & 8 & (30.8) & 15 & (57.7) & 3 & (11.5) \\
\hline $\mathbf{A}_{1}$ & 0 & (0) & 11 & (52.4) & 10 & (47.6) \\
\hline III $A_{2}$ & 0 & (0) & 10 & (47.6) & 11 & (52.4) \\
\hline B & 0 & $(0)$ & 8 & (38.1) & 13 & (61.9) \\
\hline 群 C & 0 & $(0)$ & 9 & (42.9) & 12 & (57.1) \\
\hline D & 0 & $(0)$ & 12 & (57.1) & 9 & (42.9) \\
\hline
\end{tabular}

なかった．不変はＩ群で63.9\%， II 群は61.6\%， III群 は，42.9\%であった．悪化は I 群 で8.3\%，II群は 3.8 \%，群は57.1\%であった。

効果判定の時期は，I 群，II 群では個々の症例で 1 ク 一ル終了後の所謂最大効果発現の時点で行った, 従って 効果判定の期期付個々の症例で夫々異なる事になり，効 果発現の時期，奻果持続期間は別に検討した． III群は， その経過を追って行くと全例，全身状態は哀弱し，効果 判定悪化となってしまらので効果判定の時期は, 開腹術 施行後 7 週間目，つまり I 群，I群においては薬凧投与 の1クールが終了する時期，以後で最も全身状態の良い 時期に蒋剤投与群と同様に各項目について判定を行った か，開腹衍後 7 週以後に全身状態が改善してくる症例は なく，全例 7 週目に効果判定を行った。

判定項目別に効果を見ると表8のごとくで $\mathrm{A}_{1}$ の腫殉 教果は I 群では $16.7 \%$, II 群では $23.1 \%$ に認められた。 A，B，C，Dのいずれかの 項目に奻果発現した最初の 時期を効果発現時期 とすると投与開始後，I 群では 平 均4.5週 (6.5回施行)，II群は3.5週（5.3回施行）であ り，その時の薬郕投与量，すなわち効果発現量はI群で MMC $25.9 \mathrm{mg}$, II 群は MMC $21 \mathrm{mg}, 5-\mathrm{FU} 2,625 \mathrm{mg}$, CA 210mg であった。 また，腫場縮小の始まる董煬効 果発現時期はこれよりやや遅れ，I群は6.7週（8.7回施 行), II 群は4.4週 (6.3回施行) であり, 腫湯効果発現 量は, I 群で MMC $31.6 \mathrm{mg}$, II 群で MMC $25.2 \mathrm{mg}$,
5-FU 3,150mg，CA 252mg であった。なお，無奻例で は何時までも無効でありむしろ悪化する例むあるので， 効果発現時期，効果発現量の検索は夫々の項目の有効例 について行った.

臨床的効果の効果持続期間は，I群では平均 4.4 カ月 (平均134.9日)，II群では平均6.7カ月（平均206.0日） であった。

\section{第 2 項 Karnofsky 基準}

Karnofsky 基準の結果は表 7 下段のごとくで， I 群 II 群ともに対照群の正群に比へ，臨床所見の改善を見てい るが，1－A 以上を有効とすると I 群は $22.2 \% ，$ II 群は 34.6\%と II 群の方が有効率が高かった。

1ーAはI 群で11.1\%であり，その1一Aの状態を保 った平均効果持続期間は4.1カ月であった． II 群は，15.4 \%であり平均効果持続期間は5.8カ月であった。

1-Bは，I 群で $11.1 \%$ ，II 群 $11.5 \%$ で平均効果持統 期間は，夫々7.4カ月， 8.0カ月であった。

1 -Cは，一応の完全寛解之考兵られ，見在の化学療 法の治療目標とするところであるが，II群において 2 例 の 1 -Cが認められたが，1 例は治療開始後 2 年 4 カ月 目に他施設にて死亡し，死因は癌死と考えられた．また 1 例は，治療開始後 1 年10力月目に糖尿病性腎症で死亡 した.I群に打いては 1一Cの症例はなかった。

\section{第 2 節 延命効果}

\section{第 1 項 平均生存日数}

I 群， II 群， III 群の生存中の症例を除いた生存日数は 表ののごとくである．Ｉ群，II群，III群の手術法の種類 は偶然表による X² 検定により極端な片寄りはないと判 定され，また，I群，II群， II 群とすに生存日数の分布 が正規分布であるとの仮説がすてられないことが素分布 検定により示され以下の検討に入る.

\section{III群と I 群の差の検定}

F 検定を行うと，分散比 $\mathrm{F}=8.02 て ゙, \mathrm{~L}_{1}=34, \mathrm{~L}_{2}=20$

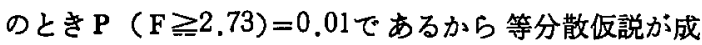
り立たないので Welch の $\mathrm{t}$ 検定によって平均値の差を 検定すると, Welch=4.31，P ( $t \geqq 2.70)=0.0$ !である から $1 \%$ 以下の危険率で，極めて有意の差を認める。上 ってI群は，四群に比へ瀕著に生存日数の延長が認めら れると判断してよい。

\section{III群と II 群の差の検定}

同様に Welch の $\mathrm{t}$ 検定により1\%以下の危険率で極 めて有意に差が説められる。つをり， II 群む壬群に比べ て生存日数が延長していると判断してよい． 
表 9 生存日数

\begin{tabular}{|c|c|c|c|}
\hline & 1 群 & II & 1110 \\
\hline $\begin{array}{ll}\text { No. } \\
2 \\
2 \\
3 \\
4 \\
4 \\
5 \\
6 \\
7 \\
7 \\
9 \\
9 \\
10 \\
11 \\
12 \\
13 \\
14 \\
15 \\
16 \\
17 \\
18 \\
19 \\
20 \\
21 \\
22 \\
23 \\
24 \\
25 \\
26 \\
27 \\
28 \\
29 \\
30 \\
31 \\
32 \\
33 \\
34 \\
35\end{array}$ & $\begin{array}{l}534 \\
249 \\
230 \\
208 \\
196 \\
192 \\
186 \\
185 \\
182 \\
179 \\
175 \\
172 \\
172 \\
172 \\
169 \\
167 \\
162 \\
154 \\
153 \\
152 \\
148 \\
141 \\
140 \\
140 \\
119 \\
112 \\
92 \\
85 \\
72 \\
60 \\
50 \\
51 \\
51 \\
50 \\
42 \\
37\end{array}$ & $\begin{array}{l}570 \\
377 \\
370 \\
255 \\
250 \\
243 \\
218 \\
213 \\
213 \\
199 \\
188 \\
185 \\
163 \\
152 \\
146 \\
132 \\
116 \\
100 \\
93 \\
75 \\
63 \\
62 \\
57 \\
48 \\
45\end{array}$ & $\begin{array}{r}154 \\
130 \\
113 \\
106 \\
97 \\
96 \\
96 \\
93 \\
93 \\
92 \\
90 \\
89 \\
85 \\
70 \\
63 \\
57 \\
52 \\
45 \\
43 \\
42 \\
40\end{array}$ \\
\hline 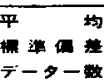 & $\begin{array}{c}152.43 \\
86.66 \\
35\end{array}$ & $\begin{array}{c}181.32 \\
122.06 \\
25\end{array}$ & $\begin{array}{c}83.14 \\
30.30 \\
21\end{array}$ \\
\hline
\end{tabular}

表10 150日以上生存例

\begin{tabular}{|c|c|c|}
\hline & I 群 & II 群 \\
\hline 例 & 19 例 & 13 测 \\
\hline 平均值 & 181.84 日 & 232.77 日 \\
\hline 㩯準㣂差 & 25.24日 & 69.73日 \\
\hline
\end{tabular}

\section{3 . I 群と II 群の差の検定}

I 群と II 群の差の検定では Welch の $\mathrm{t}$ 検定によると 有意差がない。つまり I 群と II群では II 群の方が延命効 果がありそうだという心証を搭てる必要はないが，梳計 学的には決定的なことは言えない。

そこで，これを150日以上生存した症例について検討 してみると，I群では20例，II群では14例あるが，この 5ち500日を越える症例が両群ともに 1 例ずつ含まれて おりこれが偏差を著しく大きくしているので一応両群か ら除外して検討すると平均値，標準偏差は表10のように なる.これを welch の $\mathrm{t}$ 検定によって平均値の差を検 定すると，5\%の危険率で有意差を諗める。つまり 150

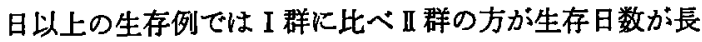
いという傾向が概孙確認できる。

\section{第 2 項 生存曲線と $50 \%$ 生存日数}

生存曲線と $50 \%$ 生存日数は表 11 のごとくで I 群, II 群
表11 生存曲楾と50生存日数

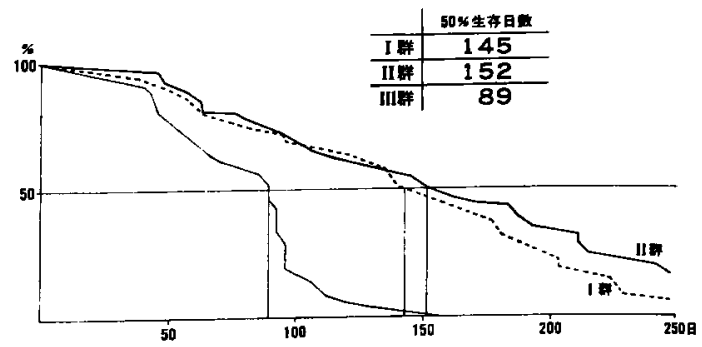

表12 副作用 (\%)

\begin{tabular}{|c|c|c|c|}
\hline & I 群 (39时) & II 群 & 31 例) \\
\hline 白血球诚少 & $18(46.2)$ & 16 & (51.6) \\
\hline 血小板娍少 & $3(7.7)$ & 11 & (35.5) \\
\hline 金欲不振 & $8 \quad(20.5)$ & 13 & $(41,9)$ \\
\hline 惠心瞘吐 & $3(7.7)$ & 9 & $(29.0)$ \\
\hline 下 $\quad$ 蔽 & $3(7.7)$ & 4 & (12.9) \\
\hline 新 & $1(2.6)$ & 1 & (3.2) \\
\hline 全身传意 & $4(10.3)$ & 7 & (22.6) \\
\hline 口内 类 & 1 (2.6) & 1 & (3.2) \\
\hline 発 & $0(0)$ & 1 & $(3,2)$ \\
\hline
\end{tabular}

間に日癌治会基準，Karnofsky 基準に見るほどの差は 認めないか150日経過を1つの境としてやや差が表われ

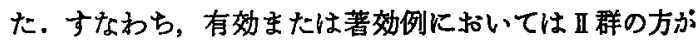
I 群に比べて，より有効な延命効果が得られているとい える。

\section{第 3 節 副作用 \\ 第 1 項 発現頻度}

副作用発現頻度は表12のごとくである。

血液学的副作用についてみると, 白血球減少は，I群 で46.2\%，II群で51.6\%，血小板减少は，I群 $7.7 \%$ ， II 群 $35.5 \%$ ，特に白血球减少については両群ともに約 半数に見られたが， II 群の方に多かった.

自覚的副作用については，食欲不振が，I群では20.5 \%，I群では41.9\%であり，副作用に関しては全般的に I 群に比し，【群に多い傾向を示した。

\section{第 2 項 発現時期}

副作用発現時期は第13のごとくで，血液学的副作用の らち白血球減少については I 群に比し II 群の発現が早か った。 また I 群 II 群とるに投与回数がふえるに従って維 時的に増加㑯向を示した．発現時期の平均は，I 群約 6.5週，II群約3.2週で，その時点での薬阂投与量は， I 群は MMC $35.5 \mathrm{mg}$, II 群は MMC 21.6mg, 5-FU 3,350mg, CA 21.6mg であった. 
表13 副作用発現時期

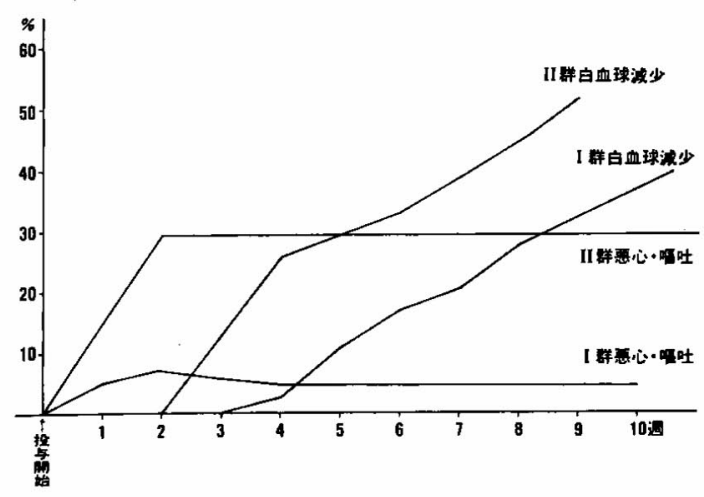

表14 病理組織学的勃果判定

\begin{tabular}{|c|c|c|c|c|c|c|}
\hline 症例 & 組綂型 & 化学療法 & 組摂学的効果 & \multicolumn{2}{|c|}{ 日瘦治基準 } & Karnoisky基蕉 \\
\hline 1 & Por & MFC & Grade IIв & 軽 & 快 & $1-B$ \\
\hline 2 & Por & MMC & Grade I & 悪 & 化 & $0-A$ \\
\hline 3 & Sig & MFC & Grade I & 軽 & 快 & $1-8$ \\
\hline 4 & Tub $_{2}$ & MFC & Grade II a & 軽 & 快 & $1-A$ \\
\hline 5 & Por & MMC & Grade I & 不 & 変 & $0-A$ \\
\hline 6 & Tub & MFC & Grade I & 不 & 変 & $1-A$ \\
\hline 7 & Tub, & MFC & Grade II a & 悪 & 化 & $0-A$ \\
\hline 8 & Tuh $_{2}$ & MMC & Grade II 8 & 軽 & 快 & $1-A$ \\
\hline
\end{tabular}

自覚的副作用のうち, 覀心呕吐は最も薬剤投与之の関 係が明瞭であり, 週 1 回ないし 2 回の化学療法施行当日 に汢必発し，化学療法施行日以外の日は軽減していると いう状態を示するのが多かった. 表13に示すように，悪 心呕吐の出現する症例 では投与開始後 2 週以内に出現 し，その後怕血球減少のように経時的に増加傾向を示 すことはなかったＩ群の中には，一度出現した悪心呕 吐が，投与を続けるらちに，消失する例もあった。また 自覚的副作用の程度は II 群の方に強く，I群では自覚的 副作用のために投与を中止した例はなかったが，II群で は 2 例の投与中止例があった.

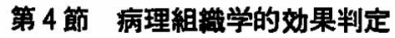

病理組織学的効果判定は表14のごとくで Grade IIA 以上は50\%に認められた. Grade II в は2例に見られ， これを臨床的效果と比較して見ると日癌治会基準では 2 例とも軽快，Karnofsky 基準では 1- B，1-A ととも に有効例であり組織学的な腫湯縮少が臨床的にす確認さ れた. 組織学的効果と臨床的效果はほぼ相関関係を示し た.

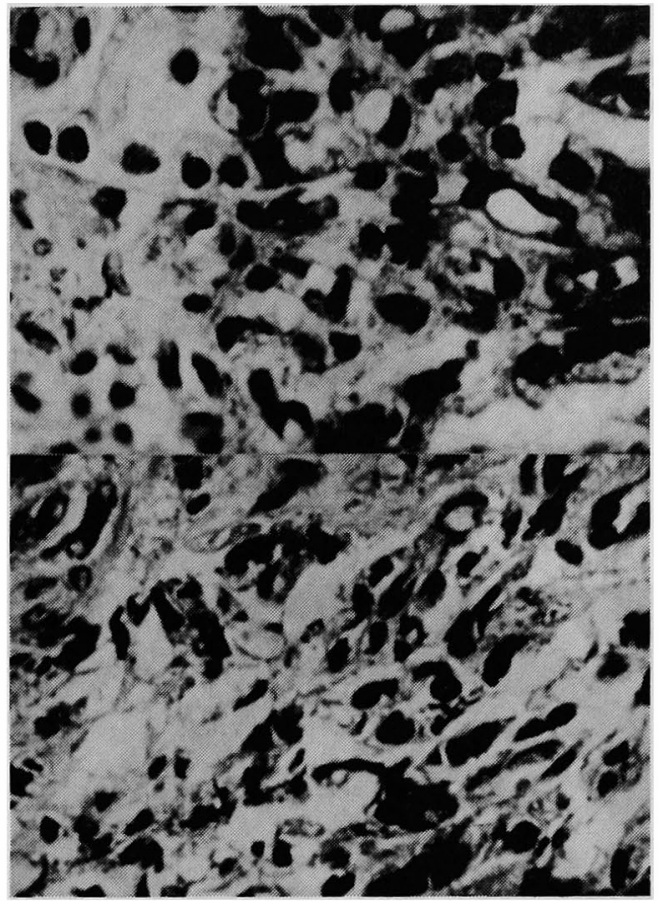

因 1 化学璄法施行前後の胃生検所見

図 1 上段は症例 1 の化学療法開始前の胃生検組織で充 実性の低分化型腺癌の像を呈する.下段は MFC 療法開 始後約 11 月後の生検組織で, 空胞変性と核濃縮を主と した変性癌細胞が增殖した間質内に环立して散在し Grade $\mathbb{I}_{\mathbf{B}}$ と判定した.

\section{第 4 章 踟床的著効症例}

\section{1. 症例 1 .}

症例 1 は，41歳，男性，II群を施行した症例である. 昭和48年 1 月頃より胃部不快感, 心骷部痛が出現し, 精 査の結果, 前庭部小弯の Borrmann II 型の訩断で, 2 月 上旬手術を施行した. 手術所見は, 癌腫に近接する腹萝 に播種性転移を認めるる $\left(\mathrm{P}_{1}\right)$, 肝転移はみられなかっ た $\left(\mathrm{H}_{0}\right)$. リンパ節転移は肝十二指腸靬帯内リンパ節, および腸間膜根部リンパ節に肉眼的転移を示し $\left(\mathrm{N}_{3}\right)$, 癌組織は粠頭部より膵体部への浸潤が著明で $\left(\mathrm{S}_{3}\right)$, 壁深 達形式はいわゆる pen 型と思われる, Stage IVのため に手術は胃空腸吻合術に終った（図2）.

術後は 2 月末日より MFC 療法を1クール行い, そ の後 1 力月 2 回の MFC 療法を加兄治療開始より 5 力 月目に腫湯の完全消失を認め, 効果は持続し 1 年 6 力月 後には $1-\mathrm{C}$ と判定したが， 2 年 4 カ月後に死亡した. 


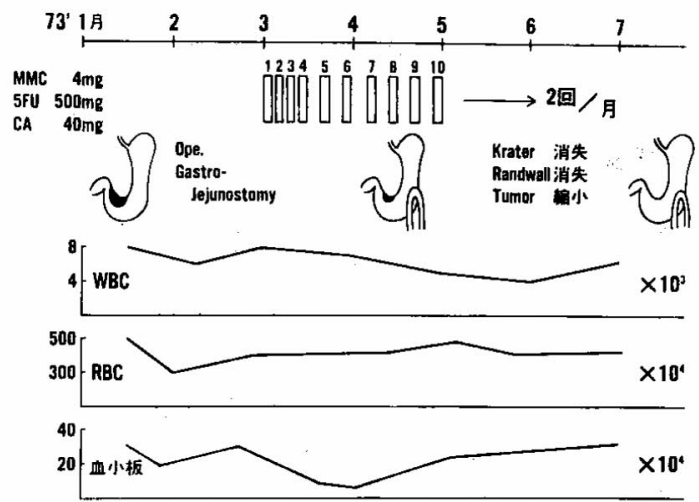

図 2 症例 141 才男性 Borr. II
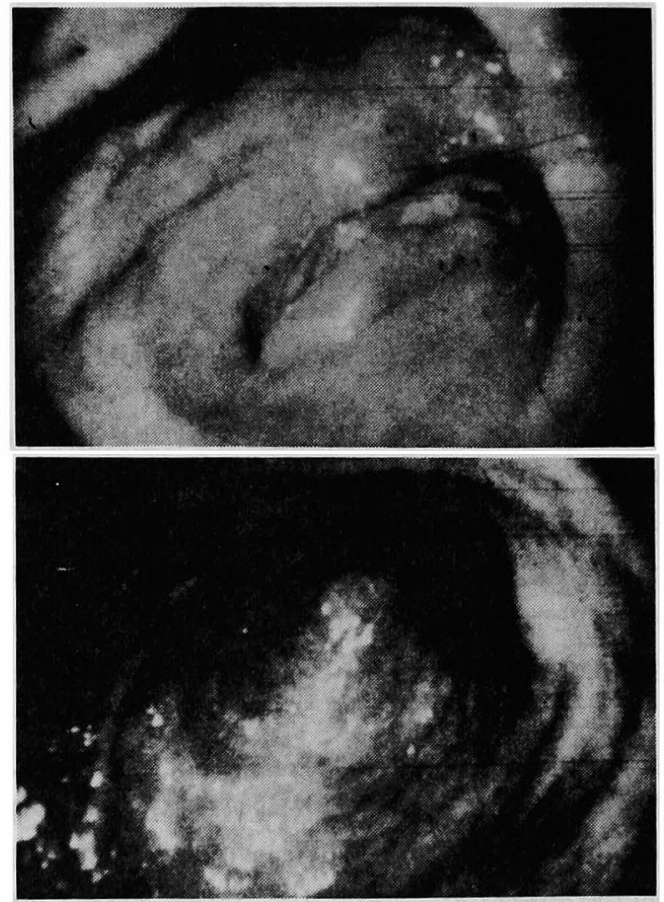

図3 症例 1 内視鏡所見

その内視鏡像は，図 3 上段のごとく加療前は前庭部小 弯寄り後壁に Borrmann II 型の Krater と Randwall が明 らかだったが，加療後 6 カ月目では下段のごとくKrater と Randwall 恃全く消失し, 定期的胃 $X$ 線, 内視鏡に上 っても腫瘍の増大, 再然の傾向は見られなかった。

2. 症例 2 .

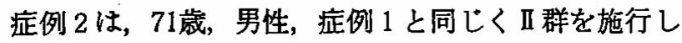
た症例である．昭和47年夏頃より全身倦急，食欲不振， 胃部不快感などがあるも放置していた。同年12月頃より

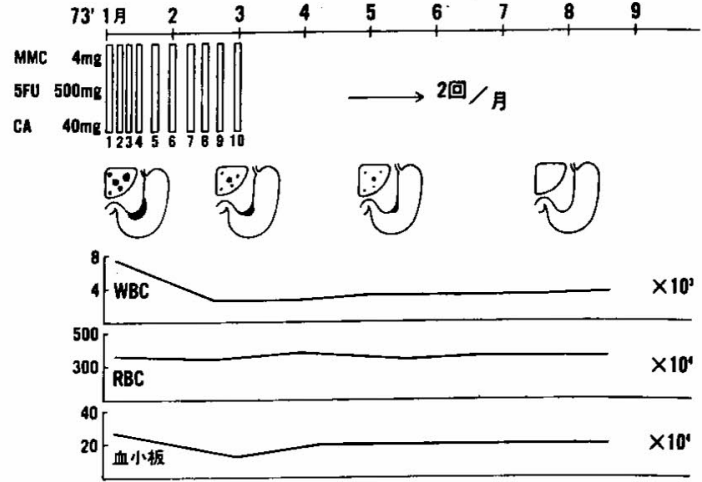

図4 症例 2 71才 男性 Borr. III

症状の增強にともない，関連病院一入院，胃 $\mathbf{X}$ 線内視鏡 などの精查の結果, 占居部位Mの Borrmann III型胃癌 で, 胃生検の結果腺管状腺癌と判明した. 入院時より腹

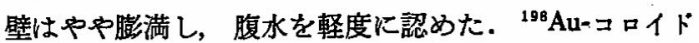
による肝シンチグラフィーの結果は, 両葉にいわゆる Space occupying lesion を欠損像として散在性に認め, 転移性所見々訅断した．忠者は，同時に糖尿病，高血 圧，心不全などああり，このため手術不能と判断した. 投与後約 7 力月後には䑐瘍の完全消失と判定するに至っ たが， 1 年10カ月目に糖尿病性腎症で死亡した，茞瘍の

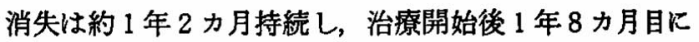
は1ーCと判定した（図 4 ).

治療前の内視鏡は図 5 左上のごとく，胃角より体中部

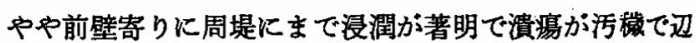
縁不整の Borrmann III 型胃癌の像を認めた（昭48，1）。 $\mathrm{MFC}$ 投与後約 1 カ月（昭48. 2) の像は右上のごとく で Randwall は平坦化し，潰鹊底部は清浄化とともに 周辺の粘膜の軟化がみられた。ささらに 2 カ月後 (昭48. 4)の像は左下のごとくで Krater は急激に縮少し, Randwall は全く平坦化して，一見良性潰演のごとき様 相を呈した.さらら 4 力月後 (昭48.7) には右下のこ とく, 陷凹性病変は全く線状癌痕状となり, 前壁寄りの 盛り上りを僅か認めるのみである。

\section{第 5 章 考 案}

\section{第 1 節 胃癌に対する化学亦法の歴史と現況}

悪性腫場に対する治療法のらち, 化学療法㓮の出現が 長い医学の歴史の中で 1 つの画期的な出来事であった事 は異論のないところである. Nitrogen mustard の出現に より，今まで不治の病とされていたりンパ肉尰，ホジキ ン病，白血病などの治療に，その道が開かれた。それ以 

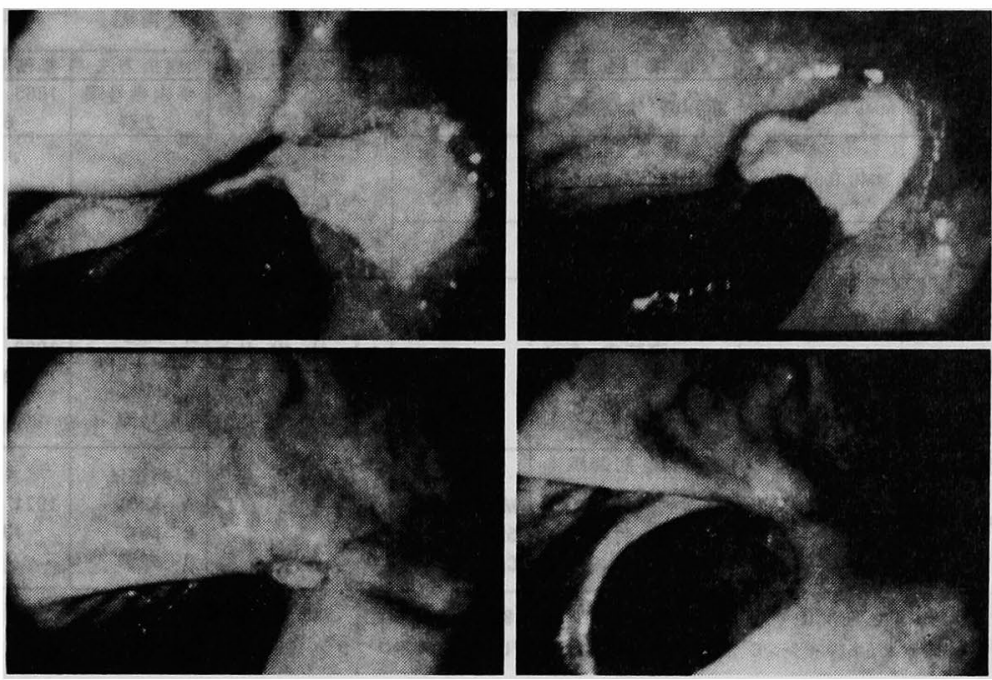

図 5 症例 2. 内視鏡所見

来数多くの薬剤が開発され，胃癌に対しても種々の薬剤 の検討がなされ，最初の単独薬剂投与から，更に有効率 の向上を目的として，種々の多剤併用療法が行われてい る.

また，化学療法単独のみならず，他の治療法との所謂 合併療法が行われ，手術療法，放射線療法，免疫療法と も同時的または異時的に併用がなされ，検討が行われて いる.

胃癌に対する単独薬剤投与としては，Cyclophosphamide, MMC, Neocarzinostatin, Adriamycin, 5-FU, FT207などが行われている。このうち MMC は代表的な薬 剤であり，現在，我か国に扎いて最も広く臨床に応用さ れている抗癌剤の1つである.

現在胃癌に対する化学療法は，単独薬剤投与と多剤併 用療法の両面から恰討が加えられているが，特に多郕併 用療法は白血病に対する化学療法をモデルとして様々な 方法が陚みられ太田 (5)4の METT, MFC, 山形ら ${ }^{5)}$ MMC, Chromomycin $\mathrm{A}_{3}$, Merphyrin, Prednisolone の併 用，木村ら ${ }^{6}$ の FAMTなど，その他にも数多くの試み がなされている、このなかで, MFC 療法は, 動物を 用いた基礎実験》に批いて，相乗効果を碓諗でき，追試 者 ${ }^{8)}$-10) とも有効性が確認されている多剂併用の代表的 な治療法の 1 つである.

\section{第 2 節 MMC 単独庵法について}

MMC は，1955年奏ら"1)により発見された放線菌 Streptomyces caespitosus の培湌濾液から得られる一群
の抗腫瘍性抗生物質 Mitomycin より分離されたもので ある. MMC は DNA 合成阻害剤であり，その殺腫瘍細 胞型式は，木村ら”の Type Ib，すなわち濃度依存性 で，な动から一定濃度下では時間依存性の性質を有す る.

胃癌に対する応用は, 芝ら ${ }^{133}$ の Mitomycin 研究会 （手術との併用班）を始めとして数多くの研究者により 有効性が確認されている(1) -18).

投与方法については, 島田ら ${ }^{14)}$ は 4 6mg 週 2 回の中 等量間歇投与が最も優れているとしている. 投与経路と しては一般的汇静脈内投与が行われているが，山田ら ${ }^{15)}$ は Seldinger 法による腹腔動脈内注入を行い，良好な成 績を報告している。

1964年厚生省癌研究班一手術と抗癌剂の併用療法研究 班一が組織され，表15に示すよらな方法で倹討が行なわ れ, 全量 $40 \mathrm{mg} / 50 \mathrm{~kg}$ の MMC を静脈内に間歇的飞約 1 カ月にかけて分割投与する厚生省第一次方式が，投与方 法, 効果, 副作用などの点からみても推蔗しらる一方法 である事が確認された ${ }^{16)}$.

著者らは, 本研究の対象が末期胃癌であるところか ら，特に副作用に対する充分なる 配虑が，必要である 事 と, その病変は単に腹腔動脈, 肝動脈などの一動脈支配 域にとどまらず，全身性におよんでいる事が推察される ために，投与経路は経静脈的，また，投与量も副作用を 恐れるあまり，いたずらに減量しても却って効果を得ら れない事になりかねないとの判断比り厚生省第一次方 


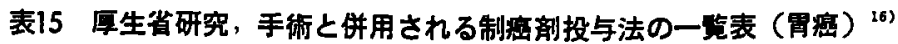

\begin{tabular}{|c|c|c|c|c|c|c|}
\hline 方 法 & 䡞绪 1 回量 & 间絰 路 & 䋨 $7 / 50 \mathrm{~kg}$ & 四茜の诲行程店 & 造択方法 & 到积期的 \\
\hline $\begin{array}{l}\text { 原生省 } \\
\text { 策1次方式 }\end{array}$ & $M M C 0.08 \mathrm{mg} / \mathrm{kg}$ & 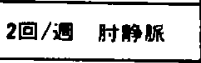 & $40 \mathrm{mg}$ & \multirow{3}{*}{$\begin{array}{c}\text { 治振手術 } \\
(\mathrm{I}, \mathrm{II}, \mathrm{III}, \mathrm{IV}) \\
\mathrm{N} \cdot \mathrm{R} \\
\text { Ho, Po } \\
\text { ow-, aw- }\end{array}$} & 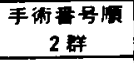 & $\begin{array}{r}1965.1 \\
-66.6 \\
\end{array}$ \\
\hline $\begin{array}{l}\text { 更生雀 } \\
\text { 第2次方式 }\end{array}$ & MMC $0.6 \mathrm{mg} / \mathrm{kg}$ & 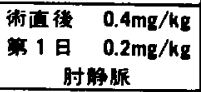 & $30 \mathrm{mg}$ & & \multirow{2}{*}{$\begin{array}{c}\text { 手術筁号原 } \\
2 \text { 群 }\end{array}$} & \multirow[t]{2}{*}{$\begin{array}{l}1966.7 \\
=68.10\end{array}$} \\
\hline 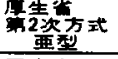 & MMC $0.4 \mathrm{mg} / \mathrm{kg}$ & 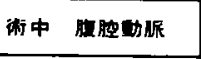 & $20 \mathrm{mg}$ & & & \\
\hline 厚生省 & MMC $26 \mathbf{m g}{ }^{* 1}$ & 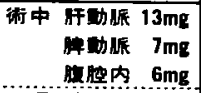 & $26 \mathrm{mg}$ & \multirow{4}{*}{ 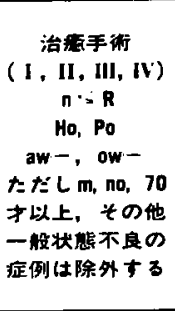 } & A： MMC & \multirow{2}{*}{$\begin{array}{l}1969.3 \\
-70.12\end{array}$} \\
\hline 乐小次 & CPA $2 \mathrm{mg} / \mathrm{kg}$ & 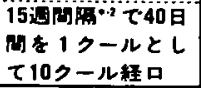 & $40 \mathrm{~g}$ & & $\begin{array}{l}\text { B : MMC } \\
\text { C : 詨照 }\end{array}$ & \\
\hline 厘生省 & $M M C 0.08 \mathrm{mg} / \mathrm{kg}$ & 2回/鸟 肘每兵 & 40mg & & \multirow[b]{2}{*}{$\begin{array}{l}\text { 封简法 } \\
\text { A : MMC } \\
\text { B：MFC } \\
\text { C：对照 }\end{array}$} & \multirow{2}{*}{$\begin{array}{l}1971.1 \\
-73.12\end{array}$} \\
\hline 第4次方式 & $\begin{array}{cc}c & M F C \\
M M C & 0.04 \mathrm{mg} / \mathrm{kg} \\
5 F U & 5 \mathrm{mg} / \mathrm{kg} \\
\text { CA } & 0.4 \mathrm{mg} / \mathrm{kg}\end{array}$ & 时觧㟲 & $\begin{array}{l}\text { MMC } 20 \mathrm{mg} \\
5 F U 2500 \mathrm{mg} \\
\text { CA } 200 \mathrm{mg}\end{array}$ & & & \\
\hline
\end{tabular}

MMC：マイトマイシンC CPA：エンドキサン 5FU：5-フルオロウラシールＣA：キロサイト

式に則った投与方法を行った.

本研究では，日癌治会基準で27.8\%，Karnofsky 基準 では 1ーA以上 $22.2 \%$ 有効率を得た。これは対照群に 比べ明らかに有効であった. MMC 単独療法の有効性

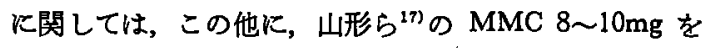
$3 \sim 4$ 日連続投与し， $2 \sim 3$ 週間の間隔で反復投与する 大量間歇 II 法による24\%の著効率, 原ら ${ }^{18)}$ の MMC 4〜 $8 \mathrm{mg}$ を週 1〜2 回投与による Karnofsky 基準 1一A以 上 $31 \%$ ，斎藤ら ${ }^{19)}$ の独自の効果判定による有効率 $22.2 \%$ などがあるがここれらの結果は，末期胃癌といえどす， 化学療法により臨床症状の改善が得られることを示し， 末期胃癌に対する化学療法の必要性を示している.

\section{第 3 節 MFC 㞠法について}

MFC 療法情野ら”のL 1210マウス白血病を用いた 併用療法の研究に打いて, MMC と 5-FU と CA は, それぞれ単独薬剮の至適有効量を投与した場合と， 3 斉 のそれぞれの 至適有効量の1/3づつを併用した 時の生存 期間の比較に乱いて，かつてないほどのすぐれた相乗 効果を示したといら実験成績にもとずいて，1969年太田 らかがこれを臨床に用いたもので，ここで多剤併用療法 の目的として, (1) 作用機序の異なる薬剂併用による制 癌スペクトラムの払大, (2) Cell cycle に対する作用点 の異なる薬剤の併用により，様々な Cell cycle にある 腫場細胞を同時に攻撃する，(3) 薬剤を併用することに よる相乗効果, (4) 副作用の分散などをあげている.

それぞれの薬剤の作用機序は，MMCについては前記 にゆずり，5-FU，CA ともに，ピリミジン代謝拮抗物質
として DNA の生合成を阻害し抗癌作用を発揮する.

これら 3 剂の多剤併用療法のポイントは，いずれる DNA 合成に関与する比較的近い点に拈いてこれを阻害 し, 前記の多剤併用療法の目的(1)の作用機序の異なる薬 剤の併用という点からは外れるが，(3)の相乗効果といら 点で優れた効果をあげているるのと思われる。

太田 'は MFC 療法の投与法をI 法からIV法に分け て検討を行ない, MMC $0.08 \mathrm{mg} / \mathrm{kg}, 5-\mathrm{FU} 10 \mathrm{mg} / \mathrm{kg}, \mathrm{CA}$ $0.8 \mathrm{mg} / \mathrm{kg}$ を初めの 2 週は週 2 回投与し, その後は週 1 回投与する MFC IV法を，効果，副作用の点から見て基 準投与法としている. 著者らの症例は，非切除非手術末 期胃癌といら手術に対する手術侵襲という副作用のため に，これを施行できなかった症例であり，化学療法の施 行に際しても副作用に対する考慮が重要であるが，一 方，化学療法は残された数少ない治療法の1つであり效 果に対しては最大の効果を得るように努力せねばなら ず，従って MFC IV法に準じた投与を行った.

胃癌に対する MFC 療法の有効率に関しては, 太田 ${ }^{201}$ は Karnofsky 基準の 1 -A以上50.0\%を，須賀ら 覚症状の改善 $63.2 \%$, 腫瘍の縮小効果 $47.6 \%$, 原ら” は Karnofsky 基準の 1 -A 以上50.0\%を, 滝野ら 癌治会基準で軽快50.0\%を挙け゚ている.

著者の結果では日癌治会基準で34.6\%の軽快, Karnofsky 基準で 1 -A 以上 $34.6 \%$ 結果を得た.これらの結 果は判定方法も多種多様で，末期胃癌と一口に云っても 実際の病状の程度は様々で，また，その判定す困難なた め一律に比較はできないか，一般に，前述の MMC 単 
独療法 ${ }^{14)-18)}$ に比へ高い有効率を示している．しかし延 命効果については必ずしる満足できるすのではなく，現 時点での癌化学療法の限界といったるのを感じせ，奻 果の持続, すなわち, 有効なる維持療法の必要性を痛感 する、しかし，著者は Karnofsky 基準の 1-Cを2例 認めこれは化学潦法の有効性と重要性を充分に示し, 例 文末期胃癌といえどすあきらめる事なく 1一A以上の有 効症例をさらに增や寸努力の必要性を示唆しているとも いえよ5。

第 4 節 MMC 単独療法と MFC 㟟法の比較につい $\tau$

著者の結果では，有効率は MMC 単独寮法に比へ

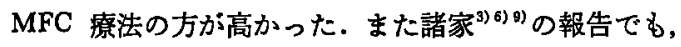
まず単独療法により，その薬剤の有効性を確認した上で 更に有奻率を高めるために多剂併用㞠法を行っている様 である.

しかし, 癌化学療法は, 腫瘍・薬剤・宿主の 3 者の面 から考えていかねばならず, adverse effect ${ }^{21)}$ の問題む あり、いたずらに過量，多種薬㶡を投与すべきではな く, 目的腫湟に対しては副作用の少ない至適薬郕を, 宿 主に対しては至適投与量および投与法で投与する事を念 頭に置くべきであろら．著者の結果でも副作用に関し ては MFC 療法の方が強く，そのための投与中止例む MFC 療法の方が多く一概に MFC 療法の方が優れてい るとは言い難い，特に末期胃癌においては，副作用に対 する宿主の抵抗力や免疫能は，当然低下していると考え られ，また，末期胃癌と一概に言っても個々の宿主の状 態，薬埥に対する反応性にす差があり，治療法の選択に 当っては，第一選択としては有効率の高い MFC 療法を 行い, 副作用などで MFC 療法が続行できないよう症例 には MMC 単独療法に変更するような考え方む必要と 思われる。

癌化学療法は白血病に対する治療を手本として発達し てきた観があるが，今後更に，寛解道入，寛解強化，維 持療法, 再寛解強化療法なと，きめの細かい治療計画, 治療方針の検討が必要であるし，単独療法か多剤併用療 法かについてむ，その時期，場合に応じ，適宣使い分け ていく必要があろ5。

\section{第 5 節 空化学港法における効果判定基準について}

現段階では，磪実な治療効果を示す癌化学療法䠼はな く，効果判定の基礎を“治瘾”をるってする事がてきな いために，その効果判定は困難で, 問題点も多い。佐藤 $5^{22)}$ は, 宿主の変化に注目し, 制癌剤使用時の体液諸因
子の変動により効果判定を行った.

増田 ${ }^{23)}$ は，尰瘍に対する直接奻果，間接所見，自覚症 状の3つの因子に分け効果判定を行った.

このような経過ののち, 表 4 に示す癌化学療法効果判 定委員会による癌化学療法効果判定基準の試案が示され た ${ }^{243}$. しかし，この試案にも問題点は多く，尰痬効果に 関しては原発巣の計湘は困難な場合が多く，自覚症状他 覚所見に関してb客観性にそしく，検查成績に関して む，当該の 5 項目で担癌生体の状態を完全に表現し得る とは思えない，またこの試案では寛解期間に関する記 載がないか;，癌化学療法の効果は患者の生存期間の延長 という点に集約されるといら事もあり，寛解期間と生存 期間は必ずしも相関関係を示さないが癌化学療法の効果 判定には寛解期間も考虑にいれる事が重要である，そこ で本研究においては Karnofsky 基準 ${ }^{25)}$ による判定す合わ せて行い生存期間に関しては延命効果として別に検索し た。

\section{第 6 節 延命効果について}

臨床的効果では軽快率などで有効性を納得できる化学 療法む延命効果を見ると，いまた不充分と云わざるを得 ない.ことに末期胃癌については尚更である。

斉藤 ${ }^{26)}$ らは昭和37〜44年度の全国集計により，末期胃 癌の化学療法開始後の 2 年生存率は $31 / 4,020(0.8 \%)$ に過ぎず， 5 年生存者に至っては，2,347例中 1 例子な かったと報告しているょらにその生命に対する予後は未 だ渗情たる現状である。

鎌田ら ${ }^{271}$ は2 年生.存率 $2.6 \%$ と諸家に比へ，良好な成 續を報告し，これを 5-FU 長期併用の効果によるものと している. 末期胃癌に対する抗癌剤の 延命効果につい ては，短期間 ではあるか，化学療法非施行群（以下非 化療群之略記）より化学療法施行群（以下化療群之略 記）の方が 生存期間が $1 \sim 4$ カ月長いとする のが多 〈20)26) 27)，特に，無効例では，非化療群と差は出ない が，有効例においては，明らかに有意の差を認めてい る. 著者の結果では, 副作用が生 ぜず1クールをきち んと計画通り投与でき, 更にその後も投与可能だった症

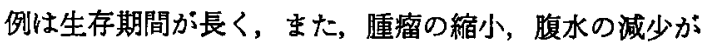
見られた症例では生存期間が長い傾向を示した。そし て，生存曲線より見ると，非化療群では90日をすざる頃 より急に生存曲線が下降するが，化療群では，この急激 な下降をある程度抑制していると思われる．それは，非 化療群では末期胃癌が更に, 病勢が悪化し, 平均約 3 カ 月で癌性悪液質に陥り死亡する所を，化療群ではこの病 
勢を抑え，楥徐な曲線を描くのではないかと思われる。 そして生存曲線は単独薬剤投与む，多剂併用㙩法もほと んど変らない下降を示すが投与後150日頃よりやや差が 現われ全般的に長期生存例は多剂併用療法に多く，この 事は統計学的検討によっても5\%の危険率で有意差があ る事が確認できた。即ち現在の化学療法では臨床効果は ある程度挙げる事が出来るが， total cell kill には達せ ず, 薬剤による寛解期間の後に病勢の再然が起り，その 時には耐性などの問題から薬剤の効果は得られず, 延命 効果も得られないのではないかと考えられる．著者の結 果ではII群で 1-Cが2例あり，これがI群とII群との 差になったと思われ，著効例は多くの症例を望めない現 状では，鎌田 ${ }^{27)}$ の云らように維持療法が重要となるが, 著者は維持療法㭗剤の条件として，（1）確実なる有効 性がある事.（2）重篤な副作用がない事. (3) Time dependent な効果を有する薬剤である事.（4）経口投 与が出来, 外来観察の可能なる事. などを考えており, 現在, I 群, II 群などの寛解導入療法に続く維持療法と して経口投与む加え鋭意検討中である。

\section{第 7 節 副作用について}

抗癌剤にとって，抗癌作用と副作用は表裹をなしてい るといってす過言ではなく，現在のところ癌細胞にのみ 選択的, 特異的に作用する薬剤はなく, 日常使用されて いる種々の薬放は多かれ少なかれ副作用を有している。

これら抗癌凧の副作用としては，血液学的副作用とし て, 貧血, 白血球減少, 栓球减少, 出血性素因などが, 自覚的副作用としては, 消化器障害に基つくものとし $\tau$, 食欲不振, 覀心, 呕吐, 下利，口内炎などがあり， その他脱毛, 皮虚炎, 色素沈着, 発熟などが挙げられて いる.

この血液学的副作用は, 主に抗癌剤の骨髄障害作用に より出現するが，MFC 療法の，MMC, 5-FU, CA の 3 剂とも白血球減少作用があり，著者の例です I 群にくら

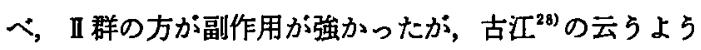
に, 副作用は必す゚しむ相乗効果を示すといら事はなく, 副作用の相加効果に勝る有効性の 相乗効果が得られれ ば，併用療法の意義を達成できると思う。

これら骨䯣障害作用に対しては，様々な予防あるいは 治療法が行なわれてきたが，現在のところ確実に有効で ある方法はない，輸血特に新鮮血の輸血は以前より広く 行われてきた予防法の1つであるが，その効果は不充分 でまた，血清肝炎などの合併症にも気をつけなければ ならない. 西村 ${ }^{29)}$ は還元型グルタチオンが MMC, 5-FU
の副作用軽隇に有効であると述ぺている，著者らは，白 血球减少を示す症例に対し，新鮮血輸血，アデニン製 剂，セファランチン製剂，イノシンなどの薬放投与を行 ったが，副作用のみに関していえば，投与量の減量や， 投与間隔を考虑する事が最む効果的であった．また免疫 化学療法としての OK-432の併用に上り白血球減少率の

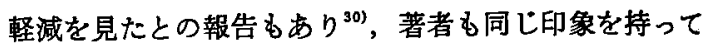
いるが，これは抗癌昘の効果を上げるととるに副作用に 関してはこれを減少させるという理想的な薬丳といらこ とがでさ興味深い。

自覚的副作用としては，消化器症状が主なるのであ り，MMC では食欲不振，悪心，呕吐，5-FU では前 などが多く見られる．久保ら ${ }^{31}$ は，これら消化器症状に 関する剖恰例の検討で，食道，胃，腸などの消化管粘膜 に点状出血, びらん，潰境形成などの所見が認められた と報告している。これら消化器症状に対しては，精神安 定剂, 自律神経遮断剂, 総合消化酵素剂, Methnchlopramide など種々の薬剂が用いられているが，確実に有効 な薬凧はない，著者らの経験では，消化器症状の軽減の ためには薬剤投与量の減量が最る有効でありこれを半量 に減量する事により 2 例を除いて投与中止を免れた. 消 化器症状の発生は個体差があり, 白血球減少のように投 与量が増すにつれて増える事はなく，投与により呕気， 呕吐などが出現する症例には必ずその他の消化器症状が 出現し，そうでないものでは，あまり問題にならないと いう印象がある。

血液学的副作用か;，化学療法を施行する医師側の苦虑 するところであるとすれば，自覚的副作用は，治療を受 ける患者側にとり最も切実な問題であろう，医療か，最 終的には，それを受ける患者のためである事を考えると 自覚的副作用の比重の大きさについては, 今後は改めて 考えなおさねばならない事を痛感している．まして本研 究のよらに末期胃癌に対する治療として, 臨床症状の改 善に有効率を求めるよらな状態では副作用は完全に効果 を相殺してしまう場合さえすあるとはいえたとえ短期 間であってる有効率は決して低くなく，また，癌による 自覚症状の軽減が得られた症例む少なくないので, 副作 用を考慮に入れつつ, 皘極的に充分な化学療法を行らぺ きと考える。

\section{第 8 節 病理組靖学的奻果判定について}

癌の化学療法を施行するにあたり延命効果が治療効果 を総体的に表現するるのであるとすると, 病理組織学的 奻果はこれに相対し，直接癌細胞に対する薬刜の効果を 
見るものでこの両面から検討して初めて薬剤の効果を云 云できるといえる．胃㴼に対する化学療法の病理組織学 的効果判定には諸家 ${ }^{23}$ 32) 33) の報告があるが組織学的変化 としては，大きく分けて癌細胞そのものに 対する変化 と，間質の变化す含めた癌細胞の消失したのちに残され た細胞欠落像，お゙よびその後に生ずる組織の収縮像によ る変化とに分けられ，また，溞細胞に対する变化は，核 の変化と細胞質の変化とに分けられる.核の変化として は，核形不整，核縁肥厚，色質粗大化，核化腫大，核内 空胞，核濃粳，核融解などがあり，細胞質の变化として は，染色性の变化，細胞質内空胞，細胞境界不明瞭化， 細胞内封入物の增加, 細胞質消失, 細胞の腫大などがあ げられる。

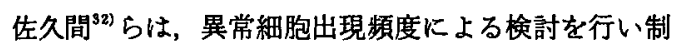
癌剤投与例は非投与例に比べ異常細胞出現頻度が高かっ たと報告し，単独薬昘投与と併用療法で組織学的な変化 の差は認めなかったとしているが著者の例です MMC 群と MFC 群では組織学的な差を見出し得なかった。 組織型については, 北出ら ${ }^{33)}$ は組織型の如何にかかわら す効果を認めたが, Carcinoma simplex の1例では無効 だったとしているが著者の例では，por と tub 2 におい て Grade II в があり組織型による有效率の差は顕著で はなかった。

大星 ${ }^{2}$ は, 癌細胞のみの変化, いわゆる細胞レベルの 変化では, 癌組織内にしばしば認められる凝固壊死巣と の鑑別が困難であり，癌胞巣のパターンまで変化が括よ

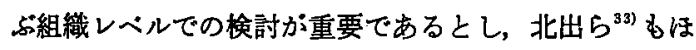
ぼそれに類する分類を行っている。そして，それには検 索材料として組織全体が必要であるが本研究では対象が 非切除，非手衍胃癌であるので生検組織による検索を行 い大星 ${ }^{2)}$ の判定基準に集して判定を行った．生検による 判定は採取部位など手技的な問題, 量的な検討に対して 不利な面などの問題はあるが，同一症例を経時的に変化 を追求出来る点などは利点であり，採取に当っては中心 の壊死組織と思われる部位はさけ，また，判定には間質 の変化も判定可能な生検材料について判定を行った. 術 前投与は検索材料として組織全体が得られるといら利点 はあるが，化学療法剮の投与量は不充分である事が多 く, 剖検材料はいわば化学療法無効例または再発再燃例 であるので臨床的な研究としては生㭘材料による榆討が 妥協点と考えている.

\section{第 6 章 結 語}

1. 62例の非切除 よよび 非手術末期胃癌に 対して癌
化療法 (I 群 MMC 単独療法36例, II 群 MFC 療法26 例)を行い，21例のコントロール群と比較検討した。

2. 日本癌治療学会効果判定基準に上る軽快率は MMC 群は27.8\%, MFC 群は, 34.6\%であった。

3. Karnofsky 基準で 1-A 以上の効果は，MMC 群 では $22.2 \%, \mathrm{MFC}$ 群では34.6\%であった。

4. MFC 群に Karnofsky $1-\mathrm{C}$ を 例認めた.

5. 延命効果は，対象群に比し，MMC 群では，50\% 生存日数で56日, 平均生存日数で69.3日, MFC 群では $50 \%$ 生存日数で63日, 平均生存日数で98.2日の延長を見 た.

6. 副作用は両群ともに認められるが，MFC 群では MMC 群に比べ出現率が高く認められた。

7. 病理組織学的効果は, 大星らの Grade I $\mathrm{I}$ 迄で あった。

8. MMC 療法, MFC 療法ともに末期胃癌の寛解導 入㞠法であった。

9. 治療効果の点では MFC 療法が優れ，副作用の 点では MMC 療法の方が軽度であった。従って症例に 応じた使い分けが必要である.

本論文の要旨は昭和50年10月第37回日本臨床外科医学 会総会, 昭和50年 12 月第 44 回東京医大癌研究会, 昭和 51 年 9 月14回日本癌治療学会にて発表した。稿を終るに臨 み，本論文の御校閲を賜わつた恩師牧野惟義教授に深甚 なる感謝の意を表します。また，終始直接御指導戴いた 相馬哲夫教授，山本啓一郎满師に深く感謝するととむ に, 研究上多くの援助と助言を戴きむした金沢策满師, 病院管理学教室中村智教授, 安紊育郎博士, 病理学教室

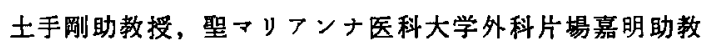
授，並びに教室員各位に感謝致します。

\section{文献}

1) 全国胃がん登録調查報告, 第 9 号，国立がん七 ンター, 東京, 1977.

2) 大星章一：化学療法の病理, 癌と化学療法, 1 : 131 134, 1974.

3) 太由和雄, 栗田宗次, 西村 穣他 : 覀性腫煬 の化学療法に括ける多剤併用療法 (METT 療 法), 最新医学, $23: 631 \sim 645,1968$.

4) 太田和雄：固型がんの多剤併用療法一MFC 療 法を中心に一, 最新医学, $28: 881 \sim 893,1973$.

5) 山形呴一, 斎藤達雄, 宇塚善郎他 : 各種制癌剤 の併用療法，第21回日癌会記事：12，1962.

6) 木村禧代二, 近田千尋, 柏田直俊他 : 腹部悪性 
畽瘍の化学療法一胃癌を中心に一，内科，19： 1314 1320, 1967.

7) 星野 章, 加藤武俊, 天羽弘行他 : Mitomycin C, 5-Fluorouracil, Cytocine Arabinoside の 3 者併用 MFC 療法に 関する基礎的研究，第 17 回日本化学療法学会総会 : 58, 1969.

8) 須賀昭二, 厷田 豊, 嶋地 崇, 小出昭彦他 : 進行癌の化学療法一とくK Mitomycin C, 5Fluorouracil, Cytosine arabinoside $の$ 併用療法 一, 癌の臨床, $18: 209 \sim 213,1972$.

9）原 義雄, 飛田祐吉, 小越和栄他 : 悪性腫湯に 対する MFC (Mitomycin C, 5-Fluorouracil, Cytosine arabinoside の三者并用) 療法につい て, 診と治, $48: 339 \sim 342,1973$.

10）滰野辰郎，阿部達生，高藤 均他：MFC 療法 一消化器がんを中心にして一, 現代の臨床，7： 111 118, 1973.

11) T. Hata, Y. Sano, R. Sugawara, et al.: Mitomycin, a new antibiotic from streptomyces. I., J. Antibiotics, Ser. A, 9: 141-146, 1956.

12）木村禧代二，仁井谷久啺，坂井保信他：抗がん 斉の殺腫瘍細胞作用型式とその投与法に関する 知見, 日本臨床, $33: 1862 \sim 1872,1975$.

13）芝 茂: 抗癌剤, 外科, 29 ：1530 1540, 1967.

14）島田信勝, 石井良治, 武石輝夫 : 覀性腫湯の化 学療法における少量持続投与と大量間歇投与, 最新医学, $19: 2319 \sim 2325,1964$.

15）山田栄吉, 宮石成一, 黒柳弥寿雄他：転移性肝 癌に対する抗癌剤の非手術的腹腔動脈内投与に つて, 多科, 32:918 924, 1970.

16）中里博昭：胃癌と制癌㧩，外科，34：1156～ 1164, 1972.

17) 山形敝一, 宇塚善郎: 進行胃癌の化学療法, 総 合臨床, $20 ： 1433 \sim 1439$, 1971 。

18）原 義雄, 飛田祐吉, 栗田雄三他 : 固型がんの 多剂併用療法, 最新医学, $28: 894 \sim 902,1973$.

19）斉藤達雄, 横山正和：胃がんの治療, 現代医 療, $6: 1419 \sim 1426,1974$.

20) 太田和雄: 癌の化学療法, 多剤併用療法, 日本 新薬, 1973.
21）近藤達平，市橋秀仁，山田久義他：制癌剤の adverse effect の発生機転, 癌の 臨床, 9 ： 241 247, 1963.

22）佐藤八郎，柚木一雄：体液諸因子の変動よりみ た制癌䠼の効果判定基準, 日癌治, 1：21〜 $25,1966$.

23) 増田正典 : 癌化学療法の 効果判定基準, 日癌 治, I : 25 31，1966.

24）山形敞一：癌化学療法の効果判定基準, 日癌 治, II : 76〜79, 1967.

25) D.A. Karnofsky: Meaningful clinical classification of therapeutic responses to anticancer drugs. Clinical Pharmacology and Therapeutics. 2: 709-712, 1961 .

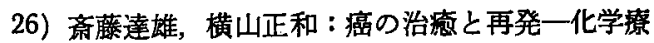
法の立場から一, 癌の 臨床, $19 ： 285-290$, 1973.

27）鎌田哲郎，暒原哲郎，坪井重雄他 : 非切除胃癌 の化学療法の効果について一とくに延命効果を 中心に一, 外科, $38: 895 \sim 898,1976$.

28）古江 尚, 中尾 功, 服部隆延：制癌剂の投与 法についての臨床的考察, 癌の臨床, $16: 896$ 909, 1970.

29）西村五郎：癌化学療法の適応と副作用, 日本臨 床外科医学会䧴誌，33：170 173，1972.

30）笹尾 哲郎, 新井 稔, 山県司政他: 進行がん に対する MFC 療法および OK-432併用療法 の臨休的検討, 癌と化学療法, 1 : 991 997, 1975.

31）久保明良, 古江 尚, 古川一介他：制癌郕飞よ る副作用, 特に消化器障害について, 診断と治 療, $42: 1158 \sim 1164,1967$.

32）佐久間 晃, 早川 勝, 渡部忠信他 : 胃癌に対 する制癌剤経口投与例の組織学的検討, 癌と化 学療法, $4: 401 \sim 406,1977$.

33）北出文男, 市岡五道, 関本 晸: 第 2 報. 胃癌 に対する術前化学療法の研究 FT-207 術前投与 例の検討，特に術前投与時に括ける組織学的效 果について, 癌と化学療法, $2: 311 \sim 314$, 1975 . 